\title{
Neurological Outcome in Fetuses with Mild and Moderate Ventriculomegaly
}

\section{Resultado neurológico em fetos com ventriculomegalia leve e moderada}

\author{
Gabriele Tonni ${ }^{1}$ Ida Vito ${ }^{1}$ Marcella Palmisano ${ }^{1}$ Wellington de Paula Martins ${ }^{2}$ Edward Araujo Júnior ${ }^{3}$ \\ ${ }^{1}$ Department of Obstetrics \& Gynecology, Guastalla Civil Hospital, \\ AUSL Reggio Emilia, Reggio Emilia, Italy \\ 2 Department of Obstetrics and Gynecology, Faculdade de Medicina \\ de Ribeirão Preto, Universidade de São Paulo (DGO-FMRP-USP) \\ Ribeirão Preto, SP, Brazil \\ ${ }^{3}$ Department of Obstetrics, Escola Paulista de Medicina, Universidade \\ Federal de São Paulo (EPM-Unifesp), São Paulo, SP, Brazil \\ Address for correspondence Edward Araujo Júnior, PhD, Rua \\ Napoleão de Barros, 875, São Paulo - SP, Brazil, CEP 04024-002 \\ (e-mail: araujojred@terra.com.br). \\ Rev Bras Ginecol Obstet 2016;38:436-442.
}

\begin{abstract}
Introduction Ventriculomegaly (VM) is one the most frequent anomalies detected on prenatal ultrasound. Magnetic resonance imaging (MRI) may enhance diagnostic accuracy and prediction of developmental outcome in newborns.

Purpose The aim of this study was to assess the correlation between ultrasound and MRI in fetuses with isolated mild and moderate VM. The secondary aim was to report the neurodevelopmental outcome at 4 years of age.

Methods Fetuses with a prenatal ultrasound (brain scan) diagnosis of VM were identified over a 4-year period. Ventriculomegaly was defined as an atrial width of 10 $15 \mathrm{~mm}$ that was further divided as mild $(10.1-12.0 \mathrm{~mm})$ and moderate (12.1-15.0 $\mathrm{mm}$ ). Fetuses with VM underwent antenatal as well as postnatal follow-ups by brain scan and MRI. Neurodevelopmental outcome was performed using the Griffiths Mental Development Scales and conducted, where indicated, until 4 years into the postnatal period.

Results Sixty-two fetuses were identified. Ventriculomegaly was bilateral in $58 \%$ of cases. A stable dilatation was seen in $45 \%$ of cases, progression was seen in $13 \%$, and

Keywords

- fetus

- ventriculomegaly

- ultrasound

- magnetic resonance imaging

- neurodevelopmental outcome regression of VM was seen in $4.5 \%$ respectively. Fetal MRI was performed in 54 fetuses and was concordant with brain scan findings in $85 \%$ of cases. Abnormal neurodevelopmental outcomes were seen in $9.6 \%$ of cases.

Conclusion Fetuses in whom a progression of VM is seen are at a higher risk of developing an abnormal neurodevelopmental outcome. Although brain scan and MRI are substantially in agreement in defining the grade of ventricular dilatation, a low correlation was seen in the evaluation of VM associated with central nervous system (CNS) or non-CNS abnormalities.
\end{abstract}

received

April 10, 2016

accepted

July 18, 2016

published online

September 9, 2016
DOI http://dx.doi.org/

$10.1055 / \mathrm{s}-0036-1592315$. ISSN $0100-7203$.
Copyright $\odot 2016$ by Thieme Publicações License terms

Ltda, Rio de Janeiro, Brazil
(1) $\Theta \circledast$ 


\section{Resumo}

\section{Palavras-chave \\ - feto \\ - ventriculomegalia \\ - ultrassom \\ - ressonância magnética \\ - desenvolvimento neurológico}

Introdução Ventriculomegalia (VM) é uma das anomalias mais frequente no ultrassom pre-natal. Ressonâncias magnéticas (RM) melhoram a precisão do diagnóstico e previsão do desenvolvimento em recém-nascidos.

Objetivo A proposta deste estudo foi avaliar a correlação entre ultrassom e RM em fetos com leve e moderada VM isolada. O objetivo secundário foi reportar o resultado neurológico na idade de 4 anos.

Métodos Fetos com diagnóstico pré-natal pelo ultrassom de VM foram identificados na idade de 4 anos. Ventriculomegalia foi definida como medida do átrio do ventrículo lateral entre $10-15 \mathrm{~mm}$, a qual foi subdividida em leve $(10,1-12,0 \mathrm{~mm})$ e moderada (12,1-15,0 mm). Fetos com VM foram seguidos nos períodos pré-natal e pós-natal por ultrassom e RM. O resultado neurológico foi realizado usando a escala de desenvolvimento mental de Griffiths, quando indicada, até a idade de 4 anos.

Resultados Sessenta e dois fetos foram identificados. Ventriculomegalia bilateral ocorreu sem $58 \%$ dos casos. Uma dilatação estável foi observada em $45 \%$, progressiva em $13 \%$ e regressiva em $4,5 \%$ dos casos, respectivamente. Ressonância magnética fetal foi realizada em 54 fetos, e foi concordante com os achados do ultrassom em $85 \%$ dos casos. Desenvolvimento neurológico anormal foi observado em 9,6\% dos casos.

Conclusão Fetos nos quais ocorreu progressão da VM são de alto risco para desenvolvimento neurológico anormal. Apesar do ultrassom e da RM mostrarem substancial concordância na definição do grau de dilatação ventricular, uma baixa correlação foi vista na avaliação da VM associada ou não com anomalias do sistema nervoso central.

\section{Introduction}

Ventriculomegaly $(\mathrm{VM})$ is one of the most common brain abnormalities observed at prenatal ultrasound (brain scan). ${ }^{1}$ The prevalence of VM varies between 0.3 and 10 per 1,000 births, depending on the technique used for the evaluation of one or both ventricles. ${ }^{2}$ Mild and moderate VM, defined as an atrial width of $10-15 \mathrm{~mm}$ between 15 and 40 weeks of gestation, may be associated with neural and extraneural malformations, fetal infections and chromosomal anomalies. ${ }^{3}$ Traditionally, the diagnosis of VM is based on prenatal brain scans during the second and the third trimesters of pregnancy. Ventriculomegaly may be isolated or associated with cranial and/or extracranial malformations, resulting in poorer prognosis in such cases. Therefore, the introduction of magnetic resonance imaging (MRI) in fetuses with a prenatally brain scan diagnosis of VM will reduce misclassified cases, thus providing a more accurate prediction of the neurodevelopmental outcome. ${ }^{4}$

The objective of this study was to compare the correlation between prenatal and postnatal brain scans with fetal and postnatal MRIs and to report the neurodevelopmental outcome at 4 years of age in infants with isolated mild and moderate VM.

\section{Methods}

The study was conducted between January 2007-2010 and approved by the local Health Board Authority of the Guastalla Civil Hospital, Reggio Emilia, Italy. Inclusion criteria were fetuses with an ultrasound diagnosis (brain scan) of isolated borderline VM at the second and third trimesters of pregnancy in whom both fetal and postnatal MRIs were available. Ventriculomegaly was defined as an atrial width of $10-$ $15 \mathrm{~mm}$ that was further divided as mild (10.1-12.0 mm) and moderate $(12.1-15.0 \mathrm{~mm}) .^{5}$ Ultrasound criteria of regression and/or progression of VM were classified as $<2$ $\mathrm{mm}$ or $>2 \mathrm{~mm}$ of lateral ventricle $(\mathrm{LV})$ measurement at the follow-up brain scan, respectively.

Fetal karyotype and TORCH analysis were evaluated in all women. Sixty-two consecutive fetuses met the study criteria. Clinical follow-up was performed at 6-48 months into the postnatal period. Transfontanelle ultrasound and MRI, electroencephalogram (EEG), Griffith test, and an ophthalmological examination were performed. Fetal and post-natal MRI were all performed at a single center and diagnosed by an expert neuroradiologist using the T2-weighted singleshot fast spin echo (SSFSE) technique, while T1-weighted images were arranged at the time of the postnatal follow-up. The MRI equipment was a 1.5 Tesla Signa Twin Speed superconducting system (GE, Milwaukee, WI, US) using an 8element phased array surface coil. Standard SSFSE imaging was performed in the fetal sagittal, coronal, and axial planes. The T2-weighted MRI settings were: repetition time (TR)/ single-shot echo time $(\mathrm{TE})=3,000 / 180$ milliseconds; matrix, $320 \times 256 ; 4 \mathrm{~mm}$ slice; field of view $[\mathrm{FOV}]=340 \mathrm{~mm}$. Axial T1-weighted sections were also acquired in gradientecho $2 \mathrm{D}(\mathrm{TR} / \mathrm{TE}=11 / 5 \mathrm{~m}$; $\mathrm{T} 1=100$ milliseconds; $5 \mathrm{~mm}$ slice; matrix, $256 \times 224$; FOV $=340 \mathrm{~mm}$; number of excitations [NEX], 3). Infinite/90; bandwidth, $32 \mathrm{kHz}$; 
FOV $=30 \times 30 \mathrm{~cm}$; matrix, $256 \times 192$; gap, $1.5 \mathrm{~mm}$; NEX, 0.5 ; refocusing pulse of less than 180 degrees; slice thickness, $4 \mathrm{~mm}$; and 0.6 second per slice, echo-train length, 72; 1 signal acquired. In addition, $\mathrm{T} 1$ axial sections weighted on the subcallosal plane were also performed with a slice of $5 \mathrm{~mm}$ and $\mathrm{TR} / \mathrm{TE}=4,000 /$ minimum; matrix, $128 \times 128$; $\mathrm{FOV}=280 \mathrm{~mm}$, all axis; $\mathrm{b} \max =600$. Griffiths Mental Development Scales measure development trends that are significant for intelligence, or indicative of functional mental growth in babies and young children from birth to the developmental age of 8 years. Within the $0-2$-year scales, a profile is obtained from 5 subscales examining locomotor, personal-social, language, eye-and-hand coordination and performance. In the 2-8-year scales, this profile is expanded to add a Practical Reasoning (General Quotient) subscale.

The neurodevelopmental outcome was collected from 12-48 months using a clinical questionnaire developed by Pediatric Neurologists and conducted by telephone interview.

\section{Results}

Sixty-two consecutives fetuses with a prenatal ultrasound diagnosis of mild and moderate isolated ventriculomegaly were identified. The mean maternal age was 32 years (range 21-41) while the mean gestational age at diagnosis was 25.6 (range 18.1-35.1) weeks of gestation. The male to female ratio was 1.9. Fetal karyotype was obtained in 33 cases (53\%) by amniocentesis, identifying 1 fetus with trisomy 21. TORCH analysis resulted negative in 57 (92\%) cases. At the brain scan, $58 \%$ of cases of VM were bilateral, and $23 \%$ of fetuses had a moderate VM. Follow-up using ultrasound demonstrated a stable VM in $45 \%$ of cases, resolution of VM in 36\%, regression in $4.5 \%$, and progression in $13 \%$ of cases. Fetal MRI was performed in 54 cases (87\%), 31 of which at a gestational age lower than than 25 weeks. Overall, MRI was concordant with ultrasound in $85 \%$ of VM cases. Six newborns (9.6\%) were found to have an abnormal neurodevelopmental outcome at 4 years of age. In 7 cases $(n=7 / 54,13 \%)$, the fetal MRI detected associated cerebral abnormalities that were undiagnosed by antenatal brain scan: 3 cases of white matter anomalies ( 1 case of micro/lissencephaly, 1 case of reduced posterior white matter and 1 case of abnormal gyration). In the 4 remaining cases, VM was associated with cerebellar vermian hypoplasia with widened supratentorial-subarachnoid spaces, 2 cases of intraventricular hemorrhage and 1 case of reduced antero-posterior diameters of the cerebral hemispheres. A postnatal transfontanellar scan was performed in 36 cases while, MRI was performed in 9 cases. - Table 1 shows the findings by brain scan, fetal and postnatal scans, as well as MRI in six cases with an adverse neurodevelopment outcome (-Figs. 1-4).

\section{Discussion}

Evaluation of the LVs is an essential part of the standard sonographic examination of the fetus. Normal-sized ven- tricles provide reassurance of the normal development of the cerebrum, while increased LVs $>15 \mathrm{~mm}$ are highly associated with major cerebral anomalies. ${ }^{6}$

The mean diameter of the atria of the LVs in normal fetuses is $7.6+0.6 \mathrm{~mm}$ throughout the pregnancy. ${ }^{7}$ The prevalence of mild and moderate VM has been reported to vary from 1.48 to 22 per 1,000 live births in the low- and in high-risk pregnancy population respectively. ${ }^{6}$ Dilatation of the LVs can variably be associated with dilatation of the 3rd and 4 th ventricles, ${ }^{5}$ and an asymmetric enlargement of the LVs is defined as a difference as a width of $\geq 2 \mathrm{~mm}$ between the two LVs. ${ }^{8}$

Ventriculomegaly recognizes multifactorial causes and may be seen isolated or associated with CNS or non-CNS malformations, fetal infections and/or chromosomal anomalies, and may occur because of primary overproduction of cerebrospinal fluid (CBF), as seen in cases of choroid plexus papilloma, ${ }^{9}$ or secondary to obstructions (communicating) of the CBF caused by the narrowing or forking of the aqueduct of Sylvius, ${ }^{10}$ Dandy-Walker complex with obstruction of the foramina of Luschka and Magendie, ${ }^{11}$ or caused by intraventricular hemorrhage, ${ }^{12-14}$ infections ${ }^{3,15-17}$ or by extrinsic processes like tumors, ${ }^{12}$ arachnoid cysts or Chiari type II malformations.

Disorders of neuronal proliferation (megalencephaly, microcephaly), neuronal migration (schizencephaly, lissencephaly), agenesis of the corpus callosum (ACC), holoprosencephaly, ${ }^{13,14,18-21}$ vascular insults, or porencephaly (secondary to destructive processes of the cerebral white matter $)^{2}$ may also be considered. Congenital viral infections and common viable trisomy are associated in 3 to $15 \%$ of cases, depending on maternal age and background risk. $^{3,16,19}$ Multiple congenital malformations in fetuses with VM are calculated to range from 10 to $76 \%$, with the lowest incidence seen for mild VM and highest incidence for moderate VM. ${ }^{3,13-16,18-22}$

Our series showed that $23 \%$ of fetuses had moderate VM, and that $58 \%$ of borderline VMs were bilateral. The prenatal brain scan follow-up demonstrated resolution in 36\%, regression in $4.5 \%$, stable dilatation in $45 \%$ and progression in $13 \%$ of cases. Brain scan findings were in agreement with those of the fetal MRI in $85 \%$ of cases. In 8 fetuses (15\%), the MRI revealed additional information that were of critical impact on counseling, antenatal management and care planning by the multispecialist team. Postnatal follow-up conducted using Griffiths Mental Development Scales revealed 6 cases $(11.7 \%)$ with abnormal neurodevelopmental outcomes.

Our findings are in keeping with those of Lam and Kumar, ${ }^{23}$ who reported 306 cases of VM in which it was demonstrated that the majority of fetuses with mild VM normalized, whereas the majority of moderate cases of VM remained stable (46\% in the mild group and $26 \%$ in the moderate group resolved; only 1 case in the severe group progressed); the rate of progression of VM increased with severity. Infants with progression of VM are at a higher risk of subsequent neurodevelopmental delay than those with nonprogression, ${ }^{4}$ even though mild VM is associated with an 
Table 1 Correlation between prenatal ultrasound, fetal and postnatal ultrasounds and magnetic resonance imaging in six cases with adverse neurodevelopment outcomes

\begin{tabular}{|c|c|c|c|c|c|c|}
\hline MA & GA & Karyotype & US (Brain Scan) & Fetal MRI & $\begin{array}{l}\text { Pregnancy out- } \\
\text { come }\end{array}$ & Postnatal outcome \\
\hline 31 & 22.1 & $46, X X$ & $\begin{array}{l}\text { Bilateral borderline VM } \\
\text { US follow-up: } \\
\text { - } 29 \text { wks: RLV } 12.5 \mathrm{~mm} / \\
\text { LLV } 11,3 \mathrm{~mm} \\
\text { - } 33 \text { wks: RLV13mm/LLV } \\
12 \mathrm{~mm}\end{array}$ & & $\begin{array}{l}\text { SVD at } 40 \text { wks } \\
\text { MRI: hippocampus } \\
\text { anomaly }\end{array}$ & $\begin{array}{l}\text { Nystagmus, visual } \\
\text { impairment }\end{array}$ \\
\hline 35 & 21 & $46, X X$ & $\begin{array}{l}\text { Unilateral borderline VM } \\
\text { (11 mm) }\end{array}$ & - & IOL at 38 wks for PE & $\begin{array}{l}\text { Mild neurodevelop- } \\
\text { mental delay }\end{array}$ \\
\hline 35 & 35 & $46, X X$ & $\begin{array}{l}\text { Unilateral moderate VL } \\
\text { (14 mm) }\end{array}$ & $\begin{array}{l}\text { Bilateral VL; } \\
\text { decreased volume } \\
\text { of the posterior } \\
\text { white matter }\end{array}$ & $\begin{array}{l}\text { IOL at } 38 \text { wks for PE. } \\
\text { Microcephaly, deep } \\
\text { hypotonia; cyst of } \\
\text { the thalamocau- } \\
\text { date sulcus, hypo- } \\
\text { plastic pons, } \\
\text { slightly rotated cer- } \\
\text { ebellar vermis }\end{array}$ & $\begin{array}{l}\text { West syndrome, } \\
\text { visual impairment, } \\
\text { moderate neuro- } \\
\text { motor impairment }\end{array}$ \\
\hline 34 & 22 & $46, X Y$ & $\begin{array}{l}\text { Bilateral, mild borderline } \\
\text { VM ( } 11 \mathrm{~mm}) \\
\text { US follow-up: } \\
\text { - } 26 \text { wks: } 13 \mathrm{~mm} / 11 \mathrm{~mm} \\
-30 \text { wks: } 15 \mathrm{~mm} / 11 \mathrm{~mm} \\
-34,36,38 \text { wks: } 7 \mathrm{~mm} / \\
11 \mathrm{~mm}\end{array}$ & $\begin{array}{l}\text { Bilateral, mild bor- } \\
\text { derline VM (10.2 } \\
\text { mm) } \\
\text { II MRI } 33 \text { wks: right } \\
\text { hydrocephalus (LV } \\
17 \mathrm{~mm}) ; \text { mild left } \\
\text { VL }(11 \mathrm{~mm})\end{array}$ & $\begin{array}{l}\text { SVD at } 40 \text { wks } \\
\text { MRI: stable LV, ab- } \\
\text { normal periventric- } \\
\text { ular neuronal } \\
\text { migration }\end{array}$ & $\begin{array}{l}\text { Epilepsy, } \\
\text { hypermetropy }\end{array}$ \\
\hline 37 & 22 & $46, X X$ & $\begin{array}{l}\text { Unilateral mild VL (11.5 } \\
\mathrm{mm})\end{array}$ & Mild unilateral VL & $\begin{array}{l}\text { C-s at } 41 \text { wks; bilat- } \\
\text { eral, mild-moderate } \\
\text { neurosensory } \\
\text { hypoacusis }\end{array}$ & $\begin{array}{l}\text { Mild neuromotor } \\
\text { delay }\end{array}$ \\
\hline 28 & 33.2 & ND & $\begin{array}{l}\text { Bilateral, borderline VM } \\
\text { (11 mm), } \\
\text { anti HPA-1 Ab-positive; } \\
\text { negative antiplatelet Ab } \\
\text { US follow-up } \\
36 \text { wks: RLV } 12 \text { mm, left } \\
\text { hydrocephalus (LV } 16 \\
\text { mm) associated with } \\
\text { septum at the level of the } \\
\text { occipital horn; choroid } \\
\text { plexus cyst }\end{array}$ & $\begin{array}{l}\text { Bilateral VM (RLV, } \\
15 \mathrm{~mm} \text {; LLV } \\
11 \mathrm{~mm}) ; \text { septum of } \\
\text { the occipital horn; } \\
\text { cyst of the thala- } \\
\text { mocaudate sulcus; } \\
\text { distorted choroid } \\
\text { plexus }\end{array}$ & $\begin{array}{l}\text { SVD at } 40 \text { wks } \\
\text { Brain Scan: ventric- } \\
\text { ular dilatation; CMV } \\
\text { reinfection } \\
\text { MRI: VM, increased } \\
\text { signal of the tem- } \\
\text { poral white matter } \\
\text { and increased ADC, } \\
\text { abnormal white } \\
\text { matter migration, } \\
\text { septum in the left } \\
\text { occipital horn, ab- } \\
\text { normal hyppocam- } \\
\text { pus gyration }\end{array}$ & $\begin{array}{l}\text { Mild neuromotor } \\
\text { impairment }\end{array}$ \\
\hline
\end{tabular}

Abbreviations: Ab, antibody; ADC, apparent diffusion coefficient; anti-HPA, anti-human platelet antigen; CMV, cytomegalovirus; C-s, cesarean section; GA, gestational age; IOL, induction of labor; LV, lateral ventricle, LLV, left lateral ventricle; MA, maternal age; MRI, magnetic resonance imaging; ND, not done; PE, preeclampsia; RLV, right lateral ventricle; SVD, spontaneous vaginal delivery; US, ultrasound; VM, ventriculomegaly; wks, weeks of gestation.

incidence of perinatal and neonatal deaths comparable to those of the general population. $3,6,15,17,24$

Valsky et $\mathrm{al}^{25}$ showed that the MRI could detect additional findings in a woman with increased maternal body mass index (8.3\%) and in 2 cases (5.5\%) with bleeding in germinal centers, while in the series of Benacerraf et al, ${ }^{26}$ the MRI revealed additional information ( $14 \%$ of the cases) in a case of cerebellar hypoplasia and in a case of enlarged cisterna magna. When the brain scan was compared with the MRI, Levine et $\mathrm{al}^{27}$ demonstrated a change in the final diagnosis in $23 \%$ of cases identified as abnormal at ultrasound, a change in counselling in $41 \%$ of cases, and a change in patient manage- ment in $13.5 \%$ of cases respectively. Similarly, Salomon et al ${ }^{28}$ concluded that the use of the fetal MRI modified obstetric management in $6 \%$ of cases, studying 185 third trimester fetuses with mild VM. Furthermore, in fetuses with apparently isolated mild VM, Ouahba et $\mathrm{al}^{4}$ showed that the MRI diagnosed major cerebral anomalies in $9 \%$ of cases, including cortical malformations, absence of the septum pellucidum, partial agenesis of the corpus callosum and agenesis of the cerebellar vermis.

Fetal MRI was diagnostic in $47.3 \%$ of cases of VM associated with CNS anomalies, while the brain scan could only detect $32.7 \%$ of cases. When VM associated with non-CNS 


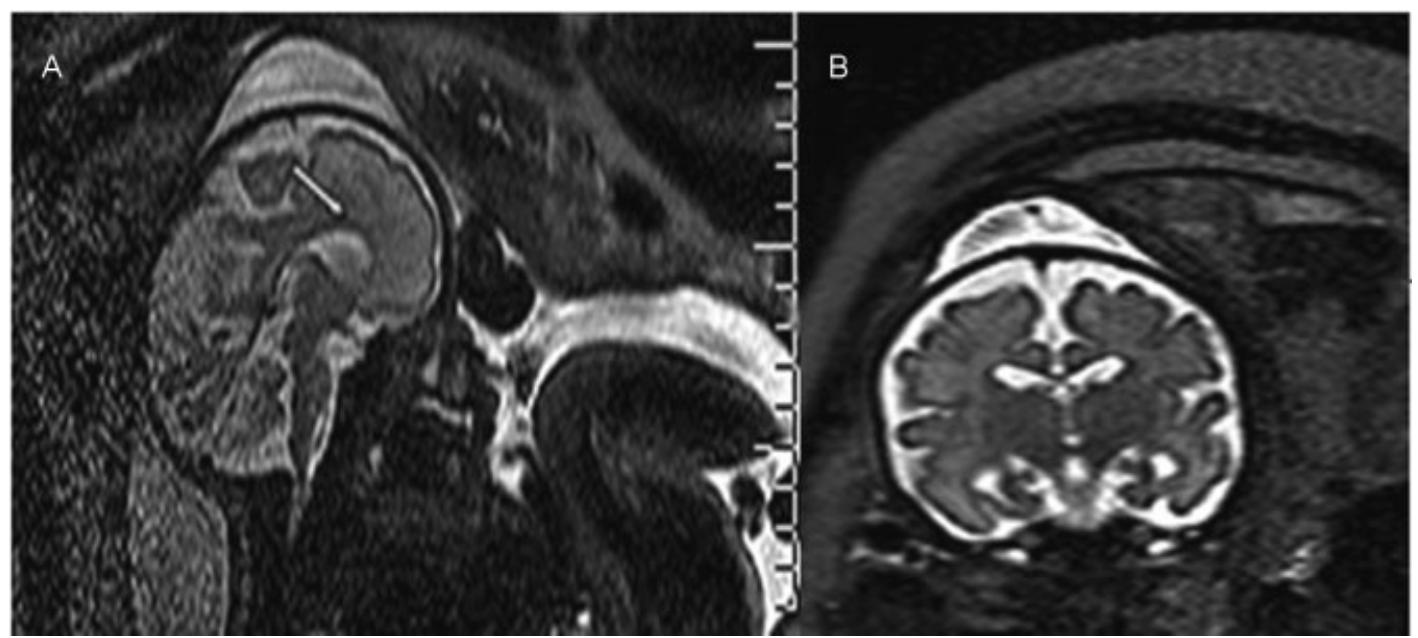

Fig. 1 T2-weighted MRI performed in a fetus at 31.3 weeks of gestation showing a thin corpus callosum (white arrow) (A) associated with mild macrocrania (B).

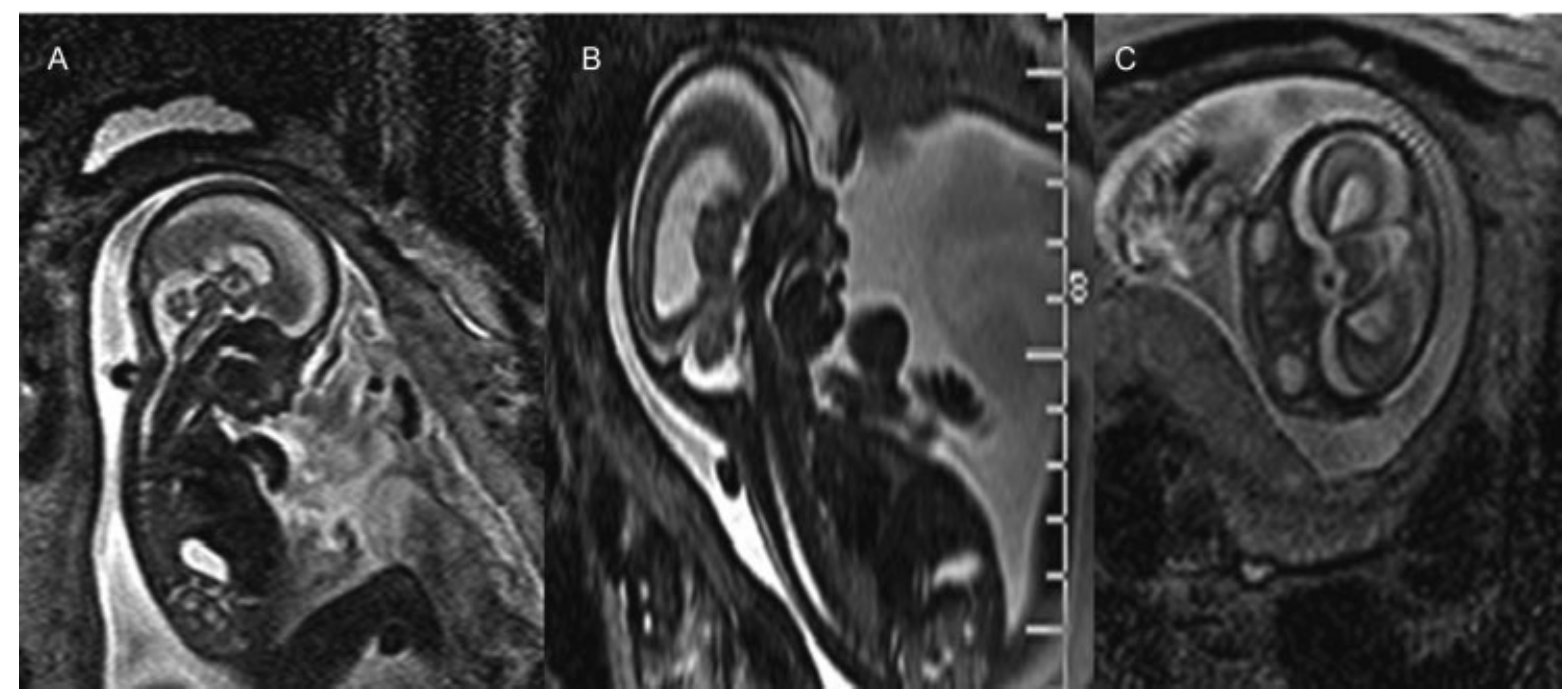

Fig. 2 T2-weighted MRI performed in a fetus at 28.4 weeks of gestation: brachycephaly (A), subcuticular frontal edema (B) and hypertelorism (C) were detected.

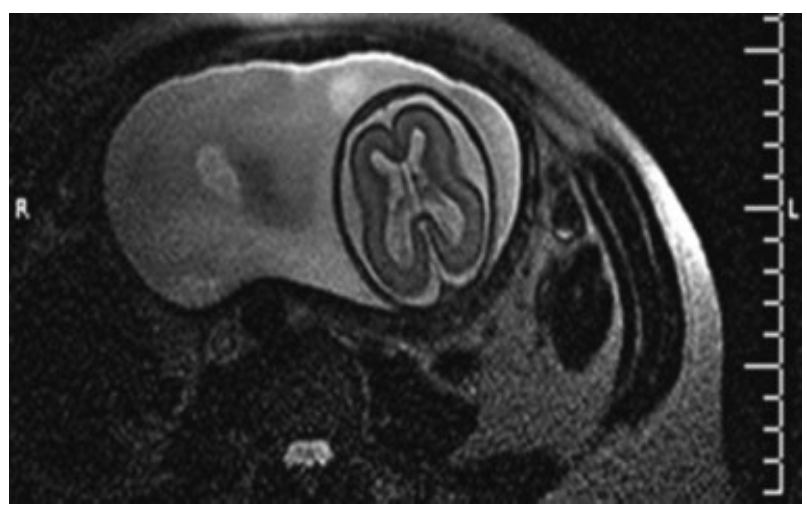

Fig. 3 T2-weighted MRI performed in a fetus at 30.5 weeks of gestation documenting reduced opercularization associated with increased periencephalic liquoral spaces. anomalies was considered, the MRI diagnosed $18.2 \%$ of cases compared with $14.5 \%$ diagnosed by ultrasound. ${ }^{29}$

Parazzini et al, ${ }^{1,30}$ on the contrary, reported disagreement between ultrasound and fetal MRI in 27.3\% of 179 fetuses with isolated mild VM at ultrasound; MRI provided additional information in a fetus with bilateral frontal schizencephaly and agenesis of the septum pellucidum, and in a fetus with isolated agenesis of the septum pellucidum. As one of the main advantages of the MRI over the ultrasound is analysis of gyration, MRI study at 30 and 32 weeks of gestation should be the most appropriate time period to perform the investigation. ${ }^{28,31}$

Prenatal brain scan diagnosis of mild, isolated VM carries a $12-13 \%$ rate of false negative results; this must be taken into consideration when counselling parents-to-be. ${ }^{32} \mathrm{Fe}-$ tuses with mild, isolated VM have good prognosis, although 


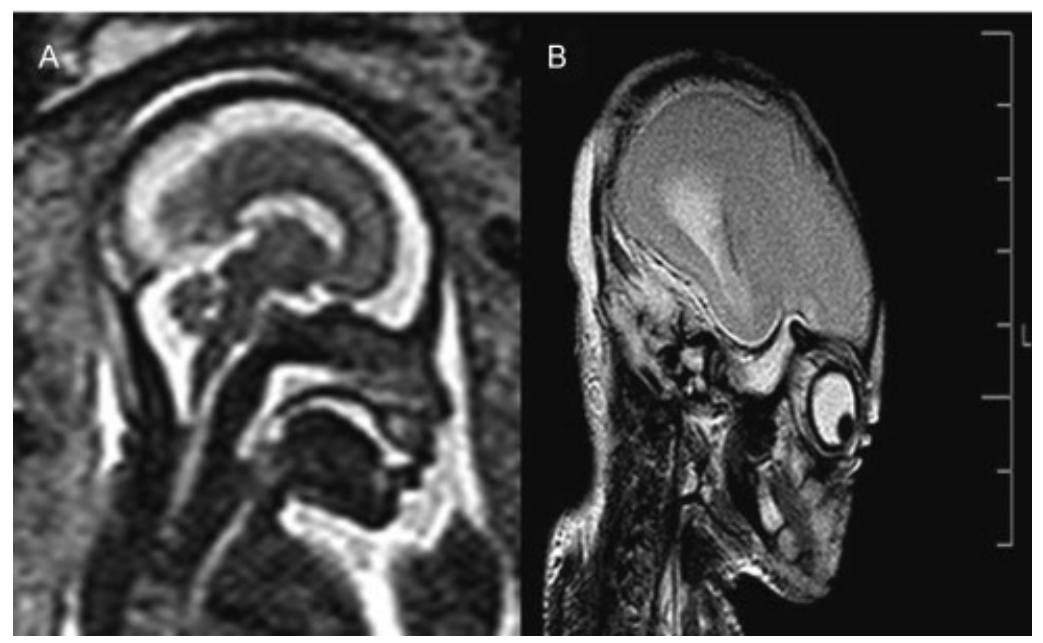

Fig. 4 T2-weighted MRI performed in a fetus at 29.3 weeks of gestation: microcephaly with microlissencephaly was prompted (A). Microlissencephaly was excluded following a postmortem MRI (B).

an overall $11 \%$ risk of neurodevelopmental delay in fetuses with isolated mild and moderate VMs is seen. ${ }^{32}$

A follow-up by brain scan between 28 and 34 weeks of gestation should be indicated in all cases of prenatally ultrasound diagnosis of $\mathrm{VM},{ }^{33}$ as the risk of progression of VM (defined as an increase in the ventricular measurement of more than $3 \mathrm{~mm}$ ) is of $\sim 16 \%{ }^{32}$ In addition, infants with progression of VM are at a higher risk of subsequent neurodevelopmental delay than those with non-progression. ${ }^{4}$ Ultrasound and MRI are substantially in agreement in defining the degree of VM (either isolated or with associated anomalies), although a low correlation between ultrasound and MRI in the evaluation of VM associated either with CNS or non-CNS anomalies has been seen. Magnetic Resonance Imaging may be a useful complementary diagnostic investigation in the detection of hemorrhagic foci, porencephaly, cortical and subependymal tubers, midline anomalies and callosal dysgenesis, as well as posterior fossa abnormalities. From 25 weeks onwards, the MRI may add additional information about cortical development and maturation, and is more accurate in detecting white matter pathology compared with the brain scan. ${ }^{34}$ Nonetheless, fetal MRI has a limited role over ultrasound in assessing the size of the cerebral ventricles, except for cases where fetal position and calvarial ossification cause reverberation artifacts and shadowing. ${ }^{35}$

In our series, the fetal MRI was performed at a mean gestational age of 31 weeks, 4 days, and allowed to detect, compared with the prenatal brain scan, the following CNS pathologies: microcephaly and microlissencephaly; suspected interventricolar septi; brachycephaly; impaired cortical gyration; cyst of the thalamocaudate sulcus; abnormal periventricular neuronal migration; increased signal of the temporal white matter and increased apparent diffusion coefficient (ADC); abnormal white matter migration; septum in the left occipital horn; and abnormal hippocampus gyra- tion. Following the analysis of the medical records and results from our series, we developed a clinical-diagnostic flowchart to be used in cases of prenatally detected isolated mild and moderate VMs ( - Fig. 5). This clinical flowchart may aid antenatal care management. Specifically, fetal karyotype, TORCH analysis, search for anti-human platelet antigen (anti-HPA) antibodies (justified only if there is a suspicion of intracranial hemorrhage on imaging) and a thorough fetal ultrasound examination should be recommended; the fetal MRI may integrate the brain scan, especially when performed in the third trimester of pregnancy, enhancing prenatal counselling and antenatal care management by

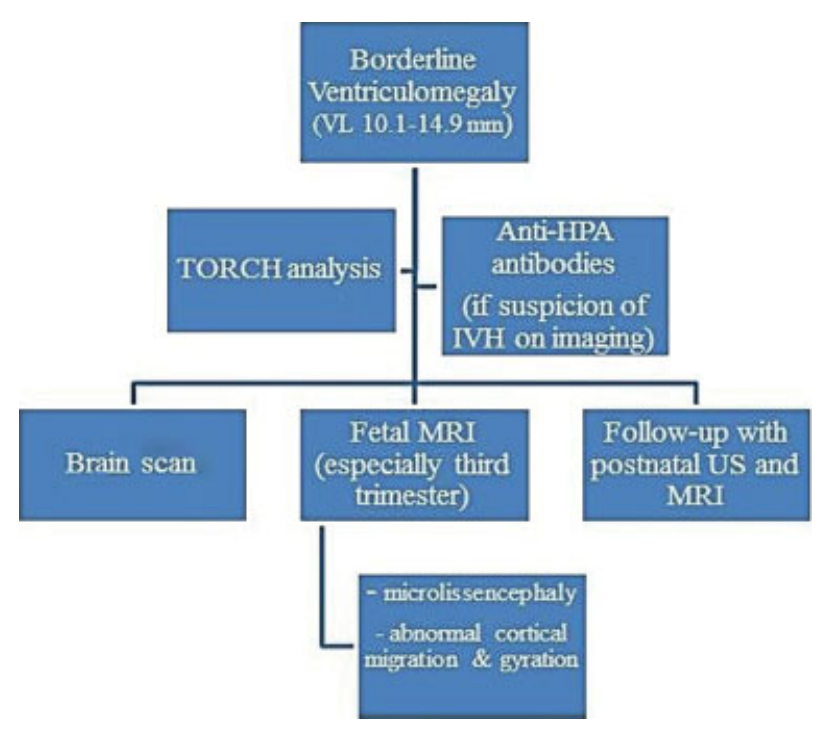

Fig. 5 Clinical-diagnostic flowchart to be used in cases of prenatally diagnosed mild and moderate ventriculomegaly. Abbreviations: anti-HPA, anti-human platelet antigen; IVH, intraventricular hemorrhage; MRI, magnetic resonance imaging; US, ultrasound; TORCH, toxoplasmosis, others, rubella, cytomegalovirus, herpes virus; VL, ventriculomegaly. 
the multispecialist team. In addition, the postnatal MRI may also allow the diagnosis of associated cerebral abnormalities undiscovered antenatally. The clinical limitations of the MRI are represented by elevated costs, availability and decreased sensitivity at a gestational age $<25$ weeks of gestation.

\section{Note}

Study performed in the Prenatal Diagnostic Unit, Department of Obstetrics \& Gynecology, Guastalla Civil Hospital, AUSL Reggio Emilia, Italy.

\section{References}

1 Parazzini C, Righini A, Doneda C, et al. Is fetal magnetic resonance imaging indicated when ultrasound isolated mild ventriculomegaly is present in pregnancies with no risk factors? Prenat Diagn 2012;32(8):752-757

2 Pilu G, Hobbins JC. Sonography of fetal cerebrospinal anomalies. Prenat Diagn 2002;22(4):321-330

3 Vergani P, Locatelli A, Strobelt N, et al. Clinical outcome of mild fetal ventriculomegaly. Am J Obstet Gynecol 1998;178(2):218-222

4 Ouahba J, Luton D, Vuillard E, et al. Prenatal isolated mild ventriculomegaly: outcome in 167 cases. BJOG 2006;113(9):1072-1079

5 Levene MI, Chervenak FA, Whittle M. Fetal and neonatal neurology and neurosurgery. 3rd ed. London: Churchill Livingstone; 2001

6 Signorelli M, Tiberti A, Valseriati D, et al. Width of the fetal lateral ventricular atrium between 10 and $12 \mathrm{~mm}$ : a simple variation of the norm? Ultrasound Obstet Gynecol 2004;23(1):14-18

7 Cardoza JD, Goldstein RB, Filly RA. Exclusion of fetal ventriculomegaly with a single measurement: the width of the lateral ventricular atrium. Radiology 1988;169(3):711-714

8 Kinzler WL, Smulian JC, McLean DA, Guzman ER, Vintzileos AM. Outcome of prenatally diagnosed mild unilateral cerebral ventriculomegaly. J Ultrasound Med 2001;20(3):257-262

9 Nejat F, Kazmi SS, Ardakani SB. Congenital brain tumors in a series of seven patients. Pediatr Neurosurg 2008;44(1):1-8

10 D’Addario V, Pinto V, Di Cagno L, Pintucci A. Sonographic diagnosis of fetal cerebral ventriculomegaly: an update. J Matern Fetal Neonatal Med 2007;20(1):7-14

11 Whitelaw A. Neonatal hydrocephalus - clinical assessment and non surgical treatment. In: Levene MI, Chervenak FA, Whittle M, editors. Fetal and neonatal neurology and surgery. 3rd ed. London: Churchill Livingstone; 2001. p. 739-61.

12 Sherer DM, Onyeije CI. Prenatal ultrasonographic diagnosis of fetal intracranial tumors: a review. Am J Perinatol 1998;15(5): 319-328

13 Fong KW, Ghai S, Toi A, Blaser S, Winsor EJ, Chitayat D. Prenatal ultrasound findings of lissencephaly associated with Miller-Dieker syndrome and comparison with pre- and postnatal magnetic resonance imaging. Ultrasound Obstet Gynecol 2004;24(7):716-723

14 Malinger G, Kidron D, Schreiber L, et al. Prenatal diagnosis of malformations of cortical development by dedicated neurosonography. Ultrasound Obstet Gynecol 2007;29(2):178-191

15 Pilu G, Falco P, Gabrielli S, Perolo A, Sandri F, Bovicelli L. The clinical significance of fetal isolated cerebral borderline ventriculomegaly: report of 31 cases and review of the literature. Ultrasound Obstet Gynecol 1999;14(5):320-326

16 Gaglioti P, Danelon D, Bontempo S, Mombrò M, Cardaropoli S, Todros T. Fetal cerebral ventriculomegaly: outcome in 176 cases. Ultrasound Obstet Gynecol 2005;25(4):372-377
17 Graham E, Duhl A, Ural S, Allen M, Blakemore K, Witter F. The degree of antenatal ventriculomegaly is related to pediatric neurological morbidity. J Matern Fetal Med 2001;10(4): 258-263

18 Pastorino D, Prefumo F, Rossi A, et al. Apparently isolated borderline ventriculomegaly and lissencephaly. Prenat Diagn 2007; 27(5):483-484

19 Nicolaides KH, Berry S, Snijders RJ, Thorpe-Beeston JG, Gosden C. Fetal lateral cerebral ventriculomegaly: associated malformations and chromosomal defects. Fetal Diagn Ther 1990;5(1):5-14

20 Mercier A, Eurin D, Mercier PY, Verspyck E, Marpeau L, Marret S. Isolated mild fetal cerebral ventriculomegaly: a retrospective analysis of 26 cases. Prenat Diagn 2001;21(7):589-595

21 Morris JE, Rickard S, Paley MN, Griffiths PD, Rigby A, Whitby EH. The value of in-utero magnetic resonance imaging in ultrasound diagnosed foetal isolated cerebral ventriculomegaly. Clin Radiol 2007;62(2):140-144

22 Breeze AC, Alexander PM, Murdoch EM, Missfelder-Lobos HH, Hackett GA, Lees CC. Obstetric and neonatal outcomes in severe fetal ventriculomegaly. Prenat Diagn 2007;27(2):124-129

23 Lam SJ, Kumar S. Evolution of fetal ventricular dilatation in relation to severity at first presentation. J Clin Ultrasound 2014;42(4):193-198

24 Gaglioti P, Oberto M, Todros T. The significance of fetal ventriculomegaly: etiology, short- and long-term outcomes. Prenat Diagn 2009;29(4):381-388

25 Valsky DV, Ben-Sira L, Porat S, et al. The role of magnetic resonance imaging in the evaluation of isolated mild ventriculomegaly. J Ultrasound Med 2004;23(4):519-523, quiz 525-526

26 Benacerraf BR, Shipp TD, Bromley B, Levine D. What does magnetic resonance imaging add to the prenatal sonographic diagnosis of ventriculomegaly? J Ultrasound Med 2007;26(11): 1513-1522

27 Levine D, Barnes PD, Robertson RR, Wong G, Mehta TS. Fast MR imaging of fetal central nervous system abnormalities. Radiology 2003;229(1):51-61

28 Salomon LJ, Ouahba J, Delezoide AL, et al. Third-trimester fetal MRI in isolated 10- to $12-\mathrm{mm}$ ventriculomegaly: is it worth it? BJOG 2006;113(8):942-947

29 Manganaro L, Savelli S, Francioso A, et al. Role of fetal MRI in the diagnosis of cerebral ventriculomegaly assessed by ultrasonography. Radiol Med (Torino) 2009;114(7):1013-1023

30 Parazzini C, Righini A, Doneda C, Rustico M, Lanna M, Triulzi F. Response to "Is fetal magnetic resonance imaging indicated when ultrasound isolated mild ventriculomegaly is present in pregnancies with no risk factors?" Prenat Diagn 2014;34(9):919

31 Garel C, Alberti C. Coronal measurement of the fetal lateral ventricles: comparison between ultrasonography and magnetic resonance imaging. Ultrasound Obstet Gynecol 2006;27(1): 23-27

32 Melchiorre K, Bhide A, Gika AD, Pilu G, Papageorghiou AT. Counseling in isolated mild fetal ventriculomegaly. Ultrasound Obstet Gynecol 2009;34(2):212-224

33 Baffero GM, Crovetto F, Fabietti I, et al. Prenatal ultrasound predictors of postnatal major cerebral abnormalities in fetuses with apparently isolated mild ventriculomegaly. Prenat Diagn 2015;35(8):783-788

34 Griffiths PD, Reeves MJ, Morris JE, et al. A prospective study of fetuses with isolated ventriculomegaly investigated by antenatal sonography and in utero MR imaging. AJNR Am J Neuroradiol 2010;31(1):106-111

35 Cardoen L, De Catte L, Demaerel P, et al. The role of magnetic resonance imaging in the diagnostic work-up of fetal ventriculomegaly. Facts Views Vis Obgyn 2011;3(3):159-163 